\title{
肠道菌群及益生菌干预: 慢性肾脏病治疗的新视角
}

\author{
朱䔏 ${ }^{1}$, 姚颖 ${ }^{1,2 *}$
}

1. 华中科技大学同济医学院附属同济医院肾内科, 武汉 430030;

2. 华中科技大学同济医学院附属同济医院临床营养科, 武汉 430030

*联系人, E-mail: yaoyingkk@126.com

2018-06-19 收稿, 2018-10-09 修回, 2018-10-10 接受, 2018-12-03 网络版发表

国家自然科学基金(81570669, 81200521, 81770684, 81673161)和内蒙古农业大学开放课题项目(KFKT201702)资助

\begin{abstract}
摘要肠道是“隐形”的免疫器官, 具有调节机体营养代谢、生理和免疫等重要功能. 近年来, 肠道菌群被认为参 与了慢性肾脏病(chronic kidney diseases, CKD) 的发生发展过程. CKD患者肠道功能屏障受到破坏，一些肠源性代 谢毒素和细菌移位进入体循环, 从而加重 $\mathrm{CKD}$ 全身炎症反应, 促进其心脑血管并发症的发生. 而益生菌治疗作为 调节肠道菌群的主要干预措施, 可能通过调节肠稳态, 减少肠源性尿毒症毒素而延缓CKD的进展. 由于益生菌对 生理功能的调节具有菌株特异性，因此根据他们的功能特性选择适当的益生菌菌株干预是至关重要的. 益生菌治 疗更新了以往探讨疾病发生发展的分子机制的理念, 为临床疾病的治疗提供了更开阔的视野. 本文主要概述了 CKD患者肠道菌群的变化以及益生菌在CKD治疗中的功效和可能作用机制.
\end{abstract}

关键词肠道菌群, 益生菌, 慢性肾脏病

人体肠道含有超过 100 万亿细菌，不同菌群共生 形成了独特的肠道微生态环境. 肠道超过 $90 \%$ 细菌 属于厚壁菌门(Firmicutes)、拟杆菌门(Bacteroidetes)、 放线菌门(Actinobacteria) 等 ${ }^{[1,2]}$. 不同的菌种在肠道 不同的位点栖息, 发挥不同的功能. 肠道菌群与宿主 的营养、代谢、生理、免疫功能密切相关. 而肠道菌 群也受到多种因素的影响, 例如饮食、药物、生活方 式、生理状态、环境和基因等 ${ }^{[3]}$. 因此, 正常的肠道 菌群对维持人体健康是至关重要的. 近年来, 随着宏 基因组学、宏转录组学以及代谢组学等技术的应用和 发展, 大量的研究开始探讨肠道菌群的组成结构和 功能变化与疾病的关系. 越来越多研究表明, 肠道菌 群失调与炎症性肠病、糖尿病、高血压、肥胖、肿瘤、 心血管疾病、神经系统疾病、过敏性疾病、风湿免疫 性疾病、慢性肾脏病等多种疾病发生发展过程相

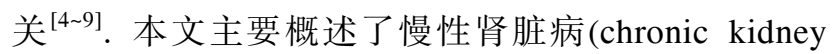

diseases，CKD)患者肠道菌群的变化以及益生菌在 $\mathrm{CKD}$ 治疗中的功效和可能作用机制.

\section{1 肠道菌群失调与慢性肾脏病}

流行病学调查结果表明, 全球范围内CKD的发 病率为 $8 \%$ 16\% ${ }^{[10,11]}$. 我国多中心调查结果也显示, 成人 CKD总患病率为 $10.8 \%, \mathrm{CKD}$ 已成为全球公共健 康问题 ${ }^{[12]}$. CKD如未能得到及时有效的治疗, 将持续 进行性发展, 最终进人到终末期肾衰竭 (end-stage renal disease, ESRD), 则需长期肾脏替代治疗. ESRD 并发症多, 心血管事件发生率显著增加, 远期预后 差，对个人及社会造成了巨大的经济负担. 越来越多 研究表明, 肾脏病患者存在明显肠道菌群紊乱 ${ }^{[13 ~ 16], ~}$ 临床研究显示, CKD患者肠道菌群丰度和组成发生 变化, ESRD患者肠道菌群中存在19种优势菌, 其中 合成硫酸吲哚酚(indoxyl sulfate, IS)的菌种有3种，硫 
酸对甲酚( p-cresyl sulfate, PCS)的2种, 而乳酸杆菌科 (Lactobacillaceae) 等益生菌显著减少 ${ }^{[14,17,18]}$. 胃肠道 内的致病菌(包括条件致病菌在内)的数量增多到一 定程度时, 将会诱发或者加重尿毒症毒素和相关细 菌毒素的积累, 加速CKD进程及并发症的发生; 同 时肠道益生菌减少也同样会对CKD患者产生不利影

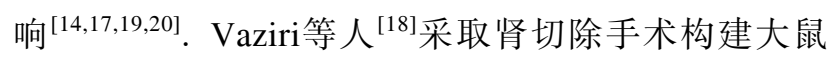
肾损伤模型, 发现肾切除大鼠的肠道菌群种类明显 减少, 说明肾损伤可以直接影响肠道菌群的种类和 数量. 我国最新研究发现, 中国ESRD患者肠道菌群 (肠型) 会从普氏菌属(Prevotella)为主转换为拟杆菌属 (Bacteroides) 为主, 这种转变与产丁酸菌的减少有 关 ${ }^{[15]}$. 尽管导致 CKD患者肠道菌群紊乱的因素仍未 明确, 一些学者认为限制性的饮食、磷结合剂、抗生 素和吸附剂等药物的使用以及CKD本身的疾病状态 在其中起着重要作用 ${ }^{[21 ~ 23]}$.

目前肠道菌群与 CKD 的关联主要体现在以下 3 个方面:

（1）肠源性尿毒症毒素合成. CKD患者肠道菌 群失调导致肠源性尿毒症毒素例如IS, PCS 和氧化三 甲胺(trimetlylamine oxide, TMAO)等生成增加, 并且 肠道菌群失调可以破坏肠道上皮的紧密连接, 增加 肠道通透性, 导致细菌和毒素的移位, 而肠源性尿毒 症毒素的聚集又会进一步加重肠道菌群紊乱, 促进 致病菌生长, 从而形成恶性循环. IS 和PCS 是不易被 透析清除的蛋白结合毒素, 已有研究表明, ESRD患 者肠道菌群中含有促进IS和PCS 合成酶的细菌丰度 更多 ${ }^{[14]}$. IS 和PCS与CKD的进展和心血管并发症的发 生密切相关. IS, PCS 可通过激发炎症和氧化应激反 应, 损伤血管内皮细胞, 增加血管通透性, 增加 CKD 血透患者的致死率 ${ }^{[2426]}$. 然而, 并不是所有的研究 都认同这一观点, 最近一项关于 1273 名透析患者的 大型队列研究认为, IS和PCS和心血管事件并无显著 相关性, 只有在低血清白蛋白透析患者的亚组中, PCS 与心血管事件显著相关, 这表明其他因素可能会 改变IS和PCS与心血管事件之间的关系 ${ }^{[27]}$. TMAO是 肠道菌群分解食物中胆碱和左旋肉碱的代谢副产物, 它被认为是心血管事件的独立危险因素, 可直接导 致动脉粥样硬化、缺血性心脏病等, 大量研究表明 CKD患者血清中TMAO含量升高可以明显增加患者 心血管事件风险和全因死亡率 ${ }^{[28 ~ 33]}$. 动物实验和临 床试验也都证明, CKD中血清TMAO升高与肠道菌群
失调直接相关 ${ }^{[13]}$.

(2) 肠道菌群引起的炎症反应. 肠道菌群失调 可促进肠道免疫炎症，进而参与 CKD的全身免疫炎 症调节, 炎症反应贯穿了 $\mathrm{CKD}$ 发生发展的全过程. 最新的人体及动物实验均表明, CKD患者肠道菌群 紊乱伴随有全身系统性炎症反应, 这主要与肠道菌 群紊乱导致肠道黏膜屏障功能失调引发的细菌移位 和毒素人血密切相关 ${ }^{[21]}$. Andersen等人 ${ }^{[23]}$ 研究发现, Collagen type $4 \alpha 3$ (Col $4 \alpha 3)$ 基因缺失小鼠构建 $\mathrm{CKD}$ 模 型可表现出全身炎症反应, 内毒素血症和肠道菌群 失调, 应用抗生素剔除兼性厌氧菌群, 可阻止细菌移 位, 减少血清内毒素, 逆转全身炎症标志物. 然而, 目前仍缺乏大规模的临床试验证实CKD患者发生肠 道菌群紊乱的同时, 也存在肠道炎症和细菌移位.

（3）营养代谢紊乱. 肠道菌群宏基因组测序发 现CKD患者肠道菌群中厚壁菌门增加而拟杆菌门减 少, 这与肥胖患者的变化极为相似, 因此认为肠道菌 群可能诱发胰岛素抵抗和营养代谢紊乱进而影响 $\mathrm{CKD}^{[34 \sim 36]}$. 藉此, Meijers等人 ${ }^{[37]}$ 提出了 $\mathrm{CKD}$ 进展和 干预的“肠-肾轴”理论(the theory of gut-kidney axis), 它是指胃肠道与肾脏相互作用, 包括胃肠道与肾脏 任何一方发生变化都会通过能量物质代谢、免疫炎 症、肠道黏膜和肠道菌群等多方面影响另一方, 并可 互为因果. 总之, 肠道与肾脏之间可以通过代谢依赖 性和免疫 2 种路径构成“肠-肾轴”而相互影响 ${ }^{[38]}$ 。“肠肾轴”介导的延缓CKD进展的理论成为近年国内外肾 病领域研究的热点之一. 总而言之, 肠道菌群紊乱会 进一步引发一系列代谢紊乱, 包括尿毒症毒素的产 生、炎症反应、氧化应激和免疫抑制等，最终也将促 进CKD的进展和心血管疾病等并发症的发生.

针对 CKD的致病原因和临床表现, 在 CKD的治 疗中, 传统有一类治疗主要针对代谢废物的堆积, 包 括减少代谢废物的产生, 如减少蛋白质的摄人或者 优质低蛋白饮食加 $\alpha$-酮酸治疗以及减少蛋白质的吸 收; 还有碳吸附剂(AST-120等)，或者增加肾脏废物 清除率, 主要指肾替代治疗, 包括透析和肾移 植 ${ }^{[39 \sim 41]}$. 以上肾脏病治疗措施可以改善或者延缓肾 脏病的进展, 但其伴随着的副作用, 比如胃肠道症 状、激素性副作用、治疗费用昂贵等也限制了这些治 疗措施在临床上的广泛应用. 因此, 开发一种新型 的，副作用更少、更无害、价格更便宜的治疗药物在 临床上减少尿毒素堆积, 延缓慢CKD的进展具有重 
要意义.

\section{2 益生菌在CKD中的应用}

益生菌作为主要调节肠道菌群的干预措施, 目 前在疾病中的研究十分火热. 益生菌是对人体有益 的一类活性微生物的总称, 它能存活于胃酸、胆汁等 生理性体液中, 通过分泌一些特异性功效的酶等增 加结肠某些共生菌浓度, 对机体产生有益作用 ${ }^{[42,43]}$. 大量研究证明, 益生菌可以改变肠道微生态环境、抑 制炎症反应、减少肠道黏膜损伤、修复受损的肠道上 皮细胞间连接并改善肠道物理屏障功能. 同时益生 菌可以竞争性增强营养物质的吸收, 减少尿毒症毒 素和铵盐类产物的堆积, 改善水电解质紊乱和酸碱 紊乱. 此外, 益生菌还可以通过其占位效应, 减少病 原体或病理性抗原与肠道黏膜受体的结合, 减轻外 源性致病体的人侵和内源性致病体的激活, 增强机 体免疫防御能力 ${ }^{[44,45]}$.

已有大量临床试验证实, 某些益生菌、益生元以 及合生元可以减少 CKD患者血清中 IS 和 PCS 等尿毒 症毒素的水平, 同时减少炎症介质的释放, 减轻结肠 上皮紧密连接的损害, 从而改善患者内毒素血症, 提 高生存质量 ${ }^{[46 \sim 99]}$. 然而, 益生菌在临床 CKD患者的 治疗仍处于试验阶段, 益生菌作用于 CKD的具体分 子机制, 益生菌对 CKD患者的长期效应等未得到解 决. 目前, 益生菌在CKD中的前期研究也主要集中 在3个方面: 减少尿毒性毒素在机体的堆积、改善慢 性炎症、改善机体代谢.

（1）减少尿毒性毒素在机体的堆积. 益生菌可 以重构肠道菌群平衡, 稳定肠道黏膜屏障, 减少肌 酐、尿素氮以及肠源性尿毒症毒素的产生和堆积, 提 高宿主免疫防御能力. 同时改善患者生存质量, 延缓 CKD患者的进展. 大量研究已经证明, 益生菌可以 减少尿毒症毒素的堆积, 减少血清肌䣫和尿素氮水 平, 在一定程度上改善了肾功能. 通过给尿素症大鼠 喂养巴氏生孢八叠球菌(Sporosarcina pasteurii)发现, 该种益生菌具有尿素靶向性, 可以直接水解尿素, 减 轻血清尿素水平, 延缓小鼠CKD的进展, 延长生存 期 ${ }^{[50]}$. 为了研究益生菌在人体的作用及可能作用机 制, Ranganathan等人 ${ }^{[51]}$ 开展了一个双盲的多中心的 临床试验, 对42例CKD-III期患者采取益生菌混合或 安慰剂疗法. 试验中发现, 益生菌治疗的患者期血清 尿素水平显著下降, 其中 12 名患者肾小球滤过率下
降速率减缓. 同时, 在一组血液透析患者的临床试验 中发现，血液透析只能轻微改善患者酚类的排泄，而 血透加口服干酪乳杆菌 (Lactobacillus casei)Shirota $(L c S) 5$ 周的患者, 其酚类和吲哚类尿毒症毒素的产生 明显减少 ${ }^{[52]}$. 在另一组试验中, 口服嗜酸乳杆菌 $(L$. acidophilus) 的 CKD患者, 其产生二甲胺和亚硝基二 甲胺的水平也下降 ${ }^{[53]}$. 最近研究还表明, 益生菌联 合益生元使用, 可改变 CKD患者肠道菌群, 减少尿 毒症毒素的产生，从而阻碍 CKD的进展及心血管疾 病发生 ${ }^{[47]}$. 以上试验均证实了益生菌可以减少尿毒 症毒素的产生和堆积, 改善机体水电解质以及代谢 紊乱. 值得关注的是, 只有肠溶性的益生菌试剂能减 少尿毒症毒素的产生. 前面我们提到在CKD患者肠 道中, 乳酸杆菌科含量明显减少, 因此这一类益生菌 最常被用于CKD的临床干预试验中.

（2）改善慢性炎症。益生菌可以改善患者慢性 炎症状态. 大量研究发现, 益生菌可以通过调控某些 信号通路，抑制促炎因子的分泌，减轻机体炎症反 应。临床试验也证实, 益生菌可以有效地减少 CKD 腹透患者血清 TNF- $\alpha$ 和IL- 6 的水平, 减少维持性血透 患者 $\mathrm{C} 反$ 应蛋白水平，抑制炎症反应 ${ }^{[54,55]}$. 然而，至 今仍少有关于益生菌在非透析CKD患者中的抗炎作 用的研究, 益生菌在CKD患者群体的广泛使用仍缺 乏更充分的实验基础. 此外, 益生菌分泌抑菌肽降低 胃肠消化道的细菌易感率，对于CKD患者具有特别 的意义. 临床 CKD患者对艰难梭菌(Clostridium difficile) 比普通病人具有更高的易感性, 因此, CKD患 者更易发生 C. difficile相关性腹泻 ${ }^{[56]}$, 加重患者水电 解质平衡紊乱. 益生菌的抑菌作用可以减少 CKD患 者C. difficile的感染, 减少肠炎以及腹泻的发生 ${ }^{[18]}$. 同时益生菌可以改善便秘, 减少毒素的吸收和蓄积, 溶解草酸石, 改善尿石症患者病情.

(3) 改善机体代谢. 大量研究表明, 益生菌可 以增加胆盐水解酶的活性, 调节肝脏胆固醇的合成, 减轻肝脏脂肪变性. 鼠李糖乳杆菌(L.rhamnosus)通 过下调脂质代谢转录基因的表达抑制胆固醇和甘油 三酯合成，同时增加脂肪酸水平 ${ }^{[57]}$. 益生菌 $(L C S)$ 尚 能改善食源性胰岛素抵抗 ${ }^{[58]}$. 益生菌也是产生短链 脂肪酸的主力军, 尤其是乳酸菌属. 其中短链脂肪酸 含量最丰富的主要为乙酸、丙酸和丁酸等, 而短链脂 肪酸不仅仅局限于肠道，维持肠道上皮的正常功能, 它还可以通过扩散作用进入血液发挥作用. 益生菌 
通过增加短链脂肪酸水平发挥抗炎作用是其产生保 护效应的机制之一, Maslowski等人 ${ }^{[59]}$ 研究发现肠道 菌群通过分泌短链脂肪酸结合 GPR43受体发挥抗炎 效应. 已有研究报道 $\mathrm{CKD}$ 患者肠道菌群紊乱, 其中 产生尿素、酚类等毒素的肠道菌群增加, 而产生短链 脂肪酸的肠道细菌减少 ${ }^{[14]}$. 也有研究证实双歧杆菌 (Bifidobacteria) 可以通过分泌乙酸改善肠道紧密连接 抑制缺血/再灌注(ischemia/reperfusion, I/R)诱导后的 细菌移位 ${ }^{[60]}$. 最新研究也认为, 膳食纤维通过选择 性调节肠道促短链脂肪酸分泌菌群, 改变短链脂肪 酸含量, 进而改善2型糖尿病 ${ }^{[61]}$. Andrade-Oliveira等 人 $^{[62]}$ 最新研究也发现乙酸可以减轻 $I / R$ 诱导的急性肾 损伤(acute kidney injury, AKI).

\section{3 目前存在的问题}

综上所述, 肠道菌群已经成为慢性肾脏病的治 疗新靶点, 益生菌干预也打开了慢性肾脏病治疗的 新视角. 但是益生菌在慢性肾脏病中的推广应用仍 存在一定问题亟待解决. 大量体内实验已经证实了 口服益生菌可以到达并黏附在肠道上皮细胞, 存活 并发挥抗菌作用 ${ }^{[63]}$. 然而尿毒症患者由于大量毒素 堆积, 肠道微环境改变, 口服益生菌后肠道益生菌的 生存率以及抗菌效应均有改变, 因此还需要更多的 实验来确认益生菌在尿毒素患者中的变化和效应. 目前也有一些方法可以提高益生菌在肠道定植的数
量及活性 ${ }^{[64]}$, 如抗胃酸材料制备的胶囊或者粪菌移 植等, 但其长远效应仍需大量实验验证. 另外, 目前 报道的益生菌对肠道微生态环境的效应评估主要通 过粪便中菌群的种类和数量来检测, 其他一些指标 也包括粪便中相关酶的活性、短链脂肪酸的含量、内 毒素浓度及肠道 $\mathrm{pH}$ 等. 但至今极少有研究用三代测 序技术证实ESRD患者肠道菌群中菌种的变化趋势和 功能分析以及服用益生菌后肠道有益菌种的变化情 况. 虽然关于益生菌对机体的保护作用已有大量研 究, 然而对于益生菌的副作用, 或者其长期应用效 应, 研究数据甚少, 仍需要高质量的大型临床试验证 实 ${ }^{[65]}$. 此外, 并不是所有的益生菌都能产生理想的 效果, 个别实验发现, 大量菌落的形成可以产生碱性 分子, 损伤肠道上皮细胞间紧密连接, 促进炎性分子 脂多糖的产生并进人血液循环, 扩散到全身. 在一项 动物研究中, 评估 5 种不同的益生菌组合对尿毒症大 鼠的作用, 只有巴氏芽狍杆菌 (Bacillus pasteurii)和 芽孢乳杆菌 (L. sporogenes) 能够降低血清尿素氮和肌 酐. 某些益生菌可以产生尿素和尿素酶, 导致上皮细 胞电阻丢失, 紧密连接蛋白缺陷, 促进尿毒症毒素和 内源性毒素的吸收, 加重尿毒症毒素在体内的蓄积, 加重内环境紊乱 ${ }^{[66]}$. 因此, 益生菌在慢性肾脏病中 研究之路仍然漫长, 建立临床大样本研究, 评估益生 菌的长效性及安全性, 并探讨不同特性益生菌对肾 脏疾病的影响具有重要意义.

\section{参考文献}

1 Eckburg P B, Bik E M, Bernstein C N, et al. Diversity of the human intestinal microbial flora. Science, 2005, 308: 1635-1638

2 Tremaroli V, Backhed F. Functional interactions between the gut microbiota and host metabolism. Nature, 2012, 489: 242-249

3 Fujisaka S, Avila-Pacheco J, Soto M, et al. Diet, genetics, and the gut microbiome drive dynamic changes in plasma metabolites. Cell Rep, 2018, 22: 3072-3086

4 Fiocchi A, Pawankar R, Cuello-Garcia C, et al. World allergy organization-McMaster University guidelines for allergic disease prevention (GLAD-P): Probiotics. World Allergy Organ J, 2015, 8: 4

$5 \mathrm{Wu} \mathrm{H}$, Esteve E, Tremaroli V, et al. Metformin alters the gut microbiome of individuals with treatment-naive type 2 diabetes, contributing to the therapeutic effects of the drug. Nat Med, 2017, 23: 850-858

6 Zhang X, Zhang D, Jia H, et al. The oral and gut microbiomes are perturbed in rheumatoid arthritis and partly normalized after treatment. Nat Med, 2015, 21: 895-905

7 Mardinoglu A, Wu H, Bjornson E, et al. An integrated understanding of the rapid metabolic benefits of a carbohydrate-restricted diet on hepatic steatosis in humans. Cell Metab, 2018, 27: 559-571. e555

8 Antza C, Stabouli S, Kotsis V. Gut microbiota in kidney disease and hypertension. Pharmacol Res, 2018, 130: 198-203

9 Maruvada P, Leone V, Kaplan L M, et al. The human microbiome and obesity: Moving beyond associations. Cell Host Microbe, 2017, 22: 589-599

10 Saran R, Li Y, Robinson B, et al. US renal data system 2014 annual data report: Epidemiology of kidney disease in the United States. Am J Kidney Dis, 2015, 66: Svii, S1-S305 
11 Jha V, Garcia-Garcia G, Iseki K, et al. Chronic kidney disease: Global dimension and perspectives. Lancet, 2013, 382: 260-272

12 Zhang L, Wang F, Wang L, et al. Prevalence of chronic kidney disease in China: A cross-sectional survey. Lancet, 2012, 379: 815-822

$13 \mathrm{Xu} \mathrm{K} \mathrm{Y,} \mathrm{Xia} \mathrm{G} \mathrm{H,} \mathrm{Lu} \mathrm{J} \mathrm{Q,} \mathrm{et} \mathrm{al.} \mathrm{Impaired} \mathrm{renal} \mathrm{function} \mathrm{and} \mathrm{dysbiosis} \mathrm{of} \mathrm{gut} \mathrm{microbiota} \mathrm{contribute} \mathrm{to} \mathrm{increased} \mathrm{trimethylamine-N-oxide}$ in chronic kidney disease patients. Sci Rep, 2017, 7: 1445

14 Wong J, Piceno Y M, DeSantis T Z, et al. Expansion of urease- and uricase-containing, indole- and p-cresol-forming and contraction of short-chain fatty acid-producing intestinal microbiota in ESRD. Am J Nephrol, 2014, 39: 230-237

15 Jiang S, Xie S, Lv D, et al. Alteration of the gut microbiota in Chinese population with chronic kidney disease. Sci Rep, 2017, 7: 2870

16 Stadlbauer V, Horvath A, Ribitsch W, et al. Structural and functional differences in gut microbiome composition in patients undergoing haemodialysis or peritoneal dialysis. Sci Rep, 2017, 7: 15601

17 Aronov P A, Luo F J, Plummer N S, et al. Colonic contribution to uremic solutes. J Am Soc Nephrol, 2011, 22: 1769-1776

18 Vaziri N D, Wong J, Pahl M, et al. Chronic kidney disease alters intestinal microbial flora. Kidney Int, 2013, 83: 308-315

19 Macfarlane G T, Macfarlane S. Bacteria, colonic fermentation, and gastrointestinal health. J AOAC Int, 2012, 95: 50-60

20 Wen L, Ley R E, Volchkov P Y, et al. Innate immunity and intestinal microbiota in the development of type 1 diabetes. Nature, 2008, 455: 1109-1113

21 Ramezani A, Raj D S. The gut microbiome, kidney disease, and targeted interventions. J Am Soc Nephrol, 2014, 25: 657-670

22 Nazzal L, Roberts J, Singh P, et al. Microbiome perturbation by oral vancomycin reduces plasma concentration of two gut-derived uremic solutes, indoxyl sulfate and p-cresyl sulfate, in end-stage renal disease. Nephrol Dial Transplant, 2017, 32: 1809-1817

23 Andersen K, Kesper M S, Marschner J A, et al. Intestinal dysbiosis, barrier dysfunction, and bacterial translocation account for CKD-related systemic inflammation. J Am Soc Nephrol, 2017, 28: 76-83

24 Bammens B, Evenepoel P, Keuleers H, et al. Free serum concentrations of the protein-bound retention solute p-cresol predict mortality in hemodialysis patients. Kidney Int, 2006, 69: 1081-1087

25 Dou L, Cerini C, Brunet P, et al. P-cresol, a uremic toxin, decreases endothelial cell response to inflammatory cytokines. Kidney Int, 2002, 62: 1999-2009

26 Cerini C, Dou L, Anfosso F, et al. P-cresol, a uremic retention solute, alters the endothelial barrier function in vitro. Thromb Haemost, 2004, 92: 140-150

27 Shafi T, Sirich T L, Meyer T W, et al. Results of the HEMO study suggest that p-cresol sulfate and indoxyl sulfate are not associated with cardiovascular outcomes. Kidney Int, 2017, 92: 1484-1492

28 Koeth R A, Wang Z, Levison B S, et al. Intestinal microbiota metabolism of L-carnitine, a nutrient in red meat, promotes atherosclerosis. Nat Med, 2013, 19: 576-585

29 Tang W H, Wang Z, Levison B S, et al. Intestinal microbial metabolism of phosphatidylcholine and cardiovascular risk. N Engl J Med, 2013, 368: 1575-1584

30 Stubbs J R, House J A, Ocque A J, et al. Serum trimethylamine-N-oxide is elevated in CKD and correlates with coronary atherosclerosis burden. J Am Soc Nephrol, 2016, 27: 305-313

31 Romano K A, Vivas E I, Amador-Noguez D, et al. Intestinal microbiota composition modulates choline bioavailability from diet and accumulation of the proatherogenic metabolite trimethylamine-N-oxide. MBio, 2015, 6: e02481

32 Kim R B, Morse B L, Djurdjev O, et al. Advanced chronic kidney disease populations have elevated trimethylamine N-oxide levels associated with increased cardiovascular events. Kidney Int, 2016, 89: 1144-1152

33 Shafi T, Powe N R, Meyer T W, et al. Trimethylamine N-oxide and cardiovascular events in hemodialysis patients. J Am Soc Nephrol, 2017, 28: 321-331

34 Kramer H J, Saranathan A, Luke A, et al. Increasing body mass index and obesity in the incident ESRD population. J Am Soc Nephrol, 2006, 17: 1453-1459

35 Nerpin E, Riserus U, Ingelsson E, et al. Insulin sensitivity measured with euglycemic clamp is independently associated with glomerular filtration rate in a community-based cohort. Diabetes Care, 2008, 31: 1550-1555

36 Ley R E, Backhed F, Turnbaugh P, et al. Obesity alters gut microbial ecology. Proc Natl Acad Sci USA, 2005, 102: 11070-11075

37 Meijers B K, Evenepoel P. The gut-kidney axis: Indoxyl sulfate, p-cresyl sulfate and CKD progression. Nephrol Dial Transplant, 2011, 26: 759-761

38 Yang T, Richards E M, Pepine C J, et al. The gut microbiota and the brain-gut-kidney axis in hypertension and chronic kidney disease. Nat Rev Nephrol, 2018, 14: 442-456

39 Miyazaki T, Aoyama I, Ise M, et al. An oral sorbent reduces overload of indoxyl sulphate and gene expression of TGF-beta1 in uraemic rat kidneys. Nephrol Dial Transplant, 2000, 15: 1773-1781

40 Vaziri N D, Yuan J, Khazaeli M, et al. Oral activated charcoal adsorbent (AST-120) ameliorates chronic kidney disease-induced intestinal 
epithelial barrier disruption. Am J Nephrol, 2013, 37: 518-525

41 Hatakeyama S, Yamamoto H, Okamoto A, et al. Effect of an oral adsorbent, AST-120, on dialysis initiation and survival in patients with chronic kidney disease. Int J Nephrol, 2012, 2012: 376128

42 Hill C, Guarner F, Reid G, et al. Expert consensus document. The international scientific association for probiotics and prebiotics consensus statement on the scope and appropriate use of the term probiotic. Nat Rev Gastroenterol Hepatol, 2014, 11: 506-514

43 Liaskovskii T M, Podgorskii V S. Assessment of probiotics according to the international organizations (FAO/WHO). Mikrobiol Z, 2005, 67: 104-112

44 Johnson-Henry K C, Hagen K E, Gordonpour M, et al. Surface-layer protein extracts from Lactobacillus helveticus inhibit enterohaemorrhagic Escherichia coli O157: H7 adhesion to epithelial cells. Cell Microbiol, 2007, 9: 356-367

45 Mack D R, Ahrne S, Hyde L, et al. Extracellular MUC3 mucin secretion follows adherence of Lactobacillus strains to intestinal epithelial cells in vitro. Gut, 2003, 52: 827-833

46 Ramezani A, Massy Z A, Meijers B, et al. Role of the gut microbiome in uremia: A potential therapeutic target. Am J Kidney Dis, 2016, 67: 483-498

47 Rossi M, Johnson D W, Morrison M, et al. Synbiotics easing renal failure by improving gut microbiology (SYNERGY): A randomized trial. Clin J Am Soc Nephrol, 2016, 11: 223-231

48 Vaziri N D, Liu S M, Lau W L, et al. High amylose resistant starch diet ameliorates oxidative stress, inflammation, and progression of chronic kidney disease. PLoS One, 2014, 9: e114881

49 Koppe L, Mafra D, Fouque D. Probiotics and chronic kidney disease. Kidney Int, 2015, 88: 958-966

50 Ranganathan N, Patel B G, Ranganathan P, et al. In vitro and in vivo assessment of intraintestinal bacteriotherapy in chronic kidney disease. ASAIO J, 2006, 52: 70-79

51 Ranganathan N, Ranganathan P, Friedman E A, et al. Pilot study of probiotic dietary supplementation for promoting healthy kidney function in patients with chronic kidney disease. Adv Ther, 2010, 27: 634-647

52 Miranda Alatriste P V, Urbina Arronte R, Gomez Espinosa C O, et al. Effect of probiotics on human blood urea levels in patients with chronic renal failure. Nutr Hosp, 2014, 29: 582-590

53 Pavan M. Influence of prebiotic and probiotic supplementation on the progression of chronic kidney disease. Minerva Urol Nefrol, 2016, 68: $222-226$

54 Wang I K, Wu Y Y, Yang Y F, et al. The effect of probiotics on serum levels of cytokine and endotoxin in peritoneal dialysis patients: A randomised, double-blind, placebo-controlled trial. Benef Microbes, 2015, 6: 423-430

55 Natarajan R, Pechenyak B, Vyas U, et al. Randomized controlled trial of strain-specific probiotic formulation (Renadyl) in dialysis patients. Biomed Res Int, 2014, 2014: 568-571

56 Aronsson B, Barany P, Nord C E, et al. Clostridium difficile-associated diarrhoea in uremic patients. Eur J Clin Microbiol, 1987, 6: 352-356

57 Falcinelli S, Picchietti S, Rodiles A, et al. Lactobacillus rhamnosus lowers zebrafish lipid content by changing gut microbiota and host transcription of genes involved in lipid metabolism. Sci Rep, 2015, 5: 9336

58 Hulston C J, Churnside A A, Venables M C. Probiotic supplementation prevents high-fat, overfeeding-induced insulin resistance in human subjects. Br J Nutr, 2015, 113: 596-602

59 Maslowski K M, Vieira A T, Ng A, et al. Regulation of inflammatory responses by gut microbiota and chemoattractant receptor GPR43. Nature, 2009, 461: 1282-1286

60 Wang H, Zhang W, Zuo L, et al. Bifidobacteria may be beneficial to intestinal microbiota and reduction of bacterial translocation in mice following ischaemia and reperfusion injury. Br J Nutr, 2013, 109: 1990-1998

61 Zhao L, Zhang F, Ding X, et al. Gut bacteria selectively promoted by dietary fibers alleviate type 2 diabetes. Science, 2018, 359: $1151-1156$

62 Andrade-Oliveira V, Amano M T, Correa-Costa M, et al. Gut bacteria products prevent AKI induced by ischemia-reperfusion. J Am Soc Nephrol, 2015, 26: 1877-1888

63 Del Piano M, Strozzi P, Barba M, et al. In vitro sensitivity of probiotics to human pancreatic juice. J Clin Gastroenterol, 2008, 42: S170-S173

64 Takayama F, Taki K, Niwa T. Bifidobacterium in gastro-resistant seamless capsule reduces serum levels of indoxyl sulfate in patients on hemodialysis. Am J Kidney Dis, 2003, 41: S142-S145

65 Buffie C G, Bucci V, Stein R R, et al. Precision microbiome reconstitution restores bile acid mediated resistance to Clostridium difficile. Nature, 2015, 517: 205-208

66 Ranganathan N, Patel B, Ranganathan P, et al. Probiotic amelioration of azotemia in 5/6th nephrectomized Sprague-Dawley rats. Sci World J, 2005, 5: 652-660 


\title{
Gut microbiota and probiotics intervention: A new therapeutic target for management of chronic kidney disease
}

\author{
Han Zhu ${ }^{1} \&$ Ying Yao ${ }^{1,2^{*}}$ \\ ${ }^{1}$ Departments of Nephrology, Tongji Hospital, Tongji Medical College, Huazhong University of Science and Technology, Wuhan 430030, China; \\ ${ }^{2}$ Departments of Nutrition, Tongji Hospital, Tongji Medical College, Huazhong University of Science and Technology, Wuhan 430030, China \\ * Corresponding author, E-mail: yaoyingkk@126.com
}

Epidemiological investigation showed that the prevalence of chronic kidney disease (CKD) is $8 \%-16 \%$. A multi-center survey in China also showed that the total prevalence of CKD in adults is $10.8 \%$, which demonstrated that CKD has become a global public health problem. Failed timely and effective treatment of CKD leads to progressive deterioration, and eventual development of end-stage renal disease (ESRD), which requires long-term renal replacement therapy. ESRD is accompanied by several complications and poor long-term prognosis, imposing a heavy economic burden on individuals and society. Therefore, delaying the progression of CKD and reducing the occurrence of ESRD is an urgent issue and currently is a trending research topic for nephrologists.

The intestinal tract can be compared to an "invisible" immune organ, capable of influencing nutrition, metabolism, physiology, and immune function in the host. Intestinal homeostasis refers to the dynamic balance between the host's mucosal barrier and intestinal microecology (including the intestinal microflora, nutritive and metabolic products, etc). The intestinal microflora is influenced by a multitude of factors such as an individual's external environment, lifestyle, eating habits, medicine intake and surgeries, etc. In recent years, gut microbiota have been considered to be involved in the occurrence and development of chronic kidney diseases (CKD). CKD is associated with impaired intestinal barrier function. Preliminary evidence indicates that toxic products generated by a dysbiotic gut microbiome and bacterial translocation may contribute to CKD progression and cardiovascular and cerebrovascular complications. The interplay between the accumulation of uremic toxins, inflammatory responses and metabolic disorders produces a vicious circle, as all three factors influence intestinal homeostasis and are crucial risk factors in the development of CKD. Therefore, it is imperative to find effective intervention measures to effectively regulate these three factors and improve intestinal homeostasis to prevent CKD progression. Probiotics, as a main intervention measure to regulate intestinal flora, may alleviate CKD progression by regulating intestinal homeostasis and reducing enteral uremic toxin. As the regulatory capacity of physiological processes by probiotics is strain specific, it is essential to choose appropriate probiotic strains according to their functional properties. Probiotics present as a new therapeutic target for management of chronic kidney disease. This review mainly summarizes the role of intestinal flora in CKD and the effect and mechanism of action of probiotics in CKD.

gut microbiota, probiotics, chronic kidney disease

doi: 10.1360/N972018-00597 